\title{
THE UNITED NATIONS CONVENTION ON THE RIGHTS OF THE CHILD - HAS THE BRIDGE BEEN CROSSED BETWEEN THEORY AND PRACTICE: MAURITIUS AND SOUTH AFRICA?
}

Introduction

On 20 November 1989 the United Nations adopted a treaty, the Convention on the Rights of the Child (hereinafter "the Convention"), which specifically focuses on a particularly vulnerable group in society at large - children (1577 UNTS 3 (1989) 28 ILM 1456). That the international community ratified this treaty so soon after its proposal is indicative of the fact that it considered this treaty as one of major importance. In accordance with Article 49 the Convention took effect and became international law on 2 September 1990. The Republic of Mauritius was quick to respond to the appeal and became a signatory in 1990. South Africa followed suit and became a signatory on 16 June 1995. The response from both these Republics is admirable, but one has to investigate how these two nations have succeeded in giving effect to their obligations as signatories. The actual provisions in the respective countries' national law will indicate the measure of true compliance with the Convention.

In this note I shall confine my discussion to article 3 and article 4 of the Convention and more specifically to the consideration of the best interests of a child where his or her parents are divorcing or separating.

\section{The convention of the rights of the child}

Recognizing the vulnerability of a child and the lack of provision for and protection of the child's right generally, the Convention responded by determining in article 3 as follows:

"1. In all actions concerning children, whether undertaken by public or private social welfare institutions, courts of law, administrative authorities or legislative bodies, the best interests of the child shall be a primary consideration.

2. State Parties undertake to ensure the child such protection and care as is necessary for his or her well-being, taking into account the rights and duties of his or her parents, legal guardians, or other individuals legally responsible for him or her, and to this end, shall take all appropriate legislative and administrative measures.

3. State Parties shall ensure that the institutions, services and facilities responsible for the care or protection of children shall conform with the 
standards established by competent authorities, particularly in the areas of safety, health, in the number and suitability of their staff, as well as competent supervision."

Article 4 reinforces this by stating that all Governments must "undertake all appropriate legislative, administrative and other measures for the implementation of the rights recognised in the present convention".

The Convention provides a universal set of standards to be adhered to by all participating countries. Besides providing a common ethical and legal framework to develop an agenda and standard for children's rights, the Convention sets a common reference against which the progress of the various participating countries can be assessed (http://www.unesco.org/ education/fresh 2004). Countries are encouraged to use the Convention as a guideline in inter alia ensuring that all legislation is compatible with the Convention (http://www.unicef.org/crc.htm 5). When considering the Convention, it becomes apparent that it has placed a proactive obligation on participating Governments to introduce whatever measures are deemed necessary to turn the principles of the Convention into reality. As a means of monitoring and supporting progress on the implementation of the Convention, the Committee on the Rights of the Child reviews and comments on the regular reports that are submitted by governments of the member countries. This committee is an internationally elected body of experts who have been elected to this position by the member countries who have ratified the Convention.

The question posed in this note is to what extent have the Republic of Mauritius and the Republic of South Africa succeeded in actually determining the meaning of "best interests" of a child, and making provision therefore domestically. Although already provided for in national legislation of certain countries worldwide predating the Convention, the actual determination of the content of the concept "best interest" is far from clear. It is an issue that has for a long time been subject to academic debate.

The Convention does not directly provide any specific criteria for the determination of the best interests of the child but the Committee on the Rights of the Child has consistently emphasized the fact that it expects the "best interests principle to be written into legislation in a way that enables it to be invoked in a court".

Have the Republics of Mauritius and South Africa succeeded in their obligation imposed by the Convention to determine and reflect on this right of the child in legislation? This question will be answered below.

\section{Mauritius}

Since its independence Mauritius has been functioning in a multi-racial and multi-cultural democracy in many ways similar to the situation in South Africa since 1994. The foundation of this democracy has been the promotion as well as the protection of basic human rights. A child is defined as a person below the age of 18 who is not married. One third of the population of 
Mauritius is made up of children (http://www2.ohchr.org/english/bodies/ crc/docs/statements/41mauritius.pdf 2).

The Government of Mauritius has indicated its firm commitment to the development and protection of children's rights. Specific measures were taken to offer concrete actions for fulfilling children's rights in line with the principles of the Convention, resulting in the amendment of some 23 pieces of national legislation amended by the National Assembly for the Protection of Children (Miscellaneous) Act and other legislation in accordance with the provisions of the Convention. In 1994 the Child Protection Act was promulgated with its main objective of providing protection to children who were the victims of neglect and abuse. Furthermore, strong and independent institutions have been founded and these institutions exist to guarantee the protection of the rights of the citizens of the country. Minister Seebun (Minister of Women's Rights, Child Development and Family Welfare) reports that since the signing of the Convention, Mauritius has pursued all efforts to provide for, and protect, the best interests of the child. The Ministry, with the assistance of UNICEF, prepared a National Children's Policy ("NCP") in 2004. The objective thereof is to establish linkages with all government institutions and NGOs relevant to co-ordinate and monitor children's policies. The NCP embodies the framework that encourages and supports the development of programmes and projects which have as their aim the promotion and protection of children's rights (Mauritius National Progress Report of The Special Session of the General Assembly on Children - "A World Fit for Children" December 2006 http://www.unicef. org/worldfitforchildren/files/Mauritius). With a view to the implementation of the policy statements of the NCP, a National Plan of Action ("NPA") has been prepared. The objective of the NPA is to ensure that children in Mauritius are protected from any form of abuse and to develop strategies and activities to be implemented by all stakeholders, including Government institutions, for the best interests of the child. Under the new government of Dr Ramgoolam, specific programmes were initiated, and Minister Seebun reported at the $41^{\text {st }}$ session of the Committee on the Rights of the Child that Mauritius had undertaken to further protect and promote children's rights during the period of 2005-2010 (http:///www2.ohchr.org/ english/bodies/crc/ docs/statements/41mauritius.pdf 2). The Minister stated that a proposal had been made to establish a Family Court in Mauritius which will have the needs and best interests of children as its primary consideration.

Has Mauritius succeeded in its objective of promoting and protecting the best interests of the child in line with its obligations of the Convention?

The Ministry of Women's Rights, Child Development, Family Welfare and Consumer Protection is mandated since 1991 to cater for children under 18 years of age (Mauritius National Progress Report of The Special Session of the General Assembly on Children - "A World Fit for Children" December 2006 http://www.unicef. org/worldfitforchildren/files/Mauritius).

One of the most important steps in ensuring the protection of children's rights was the establishment of the Office of the Ombudsperson in terms of 
the Ombudsperson for Children's Act 2003. The objectives of this office are as follows:

"The Ombudsperson for children shall -

(a) ensure that the rights, needs and interests of children are given full consideration by public bodies, private authorities, individuals and associations of individuals;

(b) promote the rights and best interests of children;

(c) promote compliance with the Convention."

The Ombudsperson is charged with the duty to carry out investigations in any matter where children are concerned and has the role of an advocate for children's rights and advises and makes proposals to government regarding compliance with the Convention (A/HRC/WG.6?4/MUS/1 9). The Ombudsperson for Children considers all situations where the rights of children born of Mauritian citizens residing either within the boundaries of Mauritius, or abroad, are concerned. The Ombudsperson for Children will also consider those instances where the rights of foreign children resident in Mauritius are questioned.

In 2005 the amendments to the Ombudsperson for Children Act made provision to

- empower the Ombudsperson for children to compel witnesses to attend and give evidence on oath before the Ombudsperson in connection with investigations conducted in terms of the Act; and to

- provide for various offences should one fail to attend and fail to take the oath as required in terms of the Act, give false evidence, insult the Ombudsperson and/or wilfully interrupt proceedings before the Ombudsperson (Mauritius National Progress Report of The Special Session of the General Assembly on Children - "A World Fit for Children" December 2006 http://www.unicef.org/worldfitforchildren/files/Mauritius).

It is clear that the Government of Mauritius considers the role of the Ombudsperson of children important.

Pivotal in determining a child's best interests is an understanding as to what is deemed to be "in the best interests of the child". Mauritian law offers no answer in this regard. The laws pertaining to children are scattered in various pieces of legislation, not one of which provides guidelines regarding factors to be considered in making this determination. It is left to the officials charged with the application of the legislation to determine that.

The Divorce and Judicial Separation Act (as amended by the Divorce and Judicial Separation (Miscellaneous Provisions Bill of 2010)) makes it mandatory for the court to hear the opinion of a child who is above the age of 10 years and is capable of discernment where a judgment is to be made concerning the custody of such child after his or her parents have divorced or separated. This provision is in accordance with the principle of the right of the child to be heard in article 12 of the Convention. Prior to this enactment, the court had a discretionary power to entertain the child's opinion. Although the welfare of the child is deemed to be paramount in determining issues of 
custody, the Act does not provide guidelines as to what ought to be considered when making a determination of the best interest of the child.

The National Children's Council Act 2003 provides that the council shall -

"(a) be the key consultative and coordinating national body on all matters related to children;

(b) protect the rights of children, promote their interest and well-being and ensure their participation in matters of interest to them; and,

(c) promote activities for the welfare of the children in the Convention of the Rights of the Child."

However, this legislation also does not provide any assistance regarding actual factors to be considered in determining the "best interest" of the child.

As early as 1996 the Committee on the Rights of the Child expressed its concern that Mauritius had not yet fully taken into account in its legislation and policies the general principles of the Convention, referring inter alia specifically to the principle of best interest of the child (Article 3 (CRC/C/15/ADD.64) 2). The Committee further noted its concern that the Convention was not an integral part of the national legislation and that national laws and regulations of Mauritius are not fully consistent with the principles and provisions of the Convention. It is important to note that international treatises ratified by Mauritius are not automatically incorporated directly into the laws of Mauritius. Where deemed necessary, changes are made to domestic legislation to enable Mauritius to comply with its treaty obligations ((A/HRC/WG.6/4/MUS/1) 12).

A consolidated Children's Bill has been proposed and action has been initiated for the drafting of the Children's Bill. The Ministry of Gender Equality, Child Development and Child Welfare is currently in the process of preparing such Bill (The Independent, 25 November 2010). The aim of this long-awaited Children's Bill will bring about a consolidated and comprehensive piece of legislation which aims to incorporate the provisions of the Convention into national Mauritian legislation, and hopefully remedy the quandry in which the Ombudsperson for Children finds herself at present in determining the best interests of the child. One of the key principles of the Convention, namely the best interests of the child is as yet not enschrined in the national legislation of Mauritius. The objective of the office of the Ombudsperson for Children is to ensure that the rights, needs and interests of children are given full consideration by public bodies, private authorities, individuals and associations for individuals to provide the rights and best interest of children and to promote compliance with the Convention (http//www.crin.org/docs/Mauritius). Clearly her position is not an easy one. As indicated above there are no legislative guidelines regarding what factors should be considered when making a determination concerning the best interests of a child in a particular case, thus making the promotion and protection of children's interests difficult.

Although Mauritius ratified the Convention very soon, an analysis of the applicable Mauritian legislation, surprisingly, indicates that not all the 
principles of the Convention have not been incorporated in national legislation. The proposed Children's Bill, which, despite numerous attempts, has not been made available to the author, or to other interested Mauritian agencies and departments, holds the promise to give effect to the principles. The Mauritian government is urged to publish the Bill and to cause the legal position concerning the best interests of the child to develop in accordance with the international requirements. Only then will there be complete compliance with the Convention. The South African approach (see below) may be of significant assistance in this regard.

\section{Republic of South Africa}

The standard of a child's best interest has often been described as a golden thread that runs through the whole fabric of South African law relating to children (Bekink and Bekink "Defining the Standard of Best Interest of the Child: Modern South African Perspectives" 2004 De Jure 21). A child is considered to be anyone below the age of 18 years. It has long been an accepted principle that the best-interest principle underpins all decisions relating to children in South Africa and ratifying the Convention was further confirmation of this. In South Africa the legal system has recognized its obligations in terms of the Convention and has been proactive in highlighting, developing, promoting and protecting the rights of the child. The Constitution has enschrined this by the inclusion of section 28(2) which provides as follows:

"the best interests of the child shall be paramount in all matters concerning the child guaranteed the consideration of the best interests of the child".

It is important to remember that the indeterminancy and judicial discretion which the best-interests standard invites, can easily lead to prejudice and discrimination (Bonthuys "The Best Interests of Children in the South African Constitution" http://www.childjustice.org). In addition, section 28(1) provides a list of specific children's rights:

"28. Children

1 Every child has the right -

a to a name and a nationality from birth;

b to family care or parental care, or to appropriate alternative care when removed from the family environment;

c to basic nutrition, shelter, basic health care services and social services;

d to be protected from maltreatment, neglect, abuse or degradation;

e to be protected from exploitative labour practices;

$f$ not to be required or permitted to perform work or provide services that -

i are inappropriate for a person of that child's age; or

ii place at risk the child's well-being, education, physical or mental health or spiritual, moral or social development;

$\mathrm{g}$ not to be detained except as a measure of last resort, in which case, in addition to the rights a child enjoys under sections 12 and 
35, the child may be detained only for the shortest appropriate period of time, and has the right to be -

i kept separately from detained persons over the age of 18 years; and

ii treated in a manner, and kept in conditions, that take account of the child's age;

$\mathrm{h}$ to have a legal practitioner assigned to the child by the state, and at state expense, in civil proceedings affecting the child, if substantial injustice would otherwise result; and

i not to be used directly in armed conflict, and to be protected in times of armed conflict."

Section 28(1) contains rights that were explicitly drawn from the
Convention.

It is clear that the legislature took note of the importance of article 3 of the Convention, and the use of the wording of the Constitution of "paramount importance" as apposed to "primary importance" in the Convention, suggests the approach that children's interests trump all their rights and interests (Reece 1996 (49) current Legal Problems 267). All sections, however, remained subject to the limitations clause in section 36 of the Constitution.

The question posed is whether or not the court is in a position to reach a decision based on what is in fact in the best interests of the child considering the limited information it may have before it on which to base its decision.

Moreover, has South Africa reached our goal as set in terms of article 3 of the Convention?

Each case ought to be decided on its own merits, but it is submitted that the courts were correct in developing certain guidelines to be taken into consideration as relevant factors when making a determination of the case on the facts before it. Of concern here is the fact that in a vast majority of cases, the court was not in a position to make a decision on the evaluation of the best interests if the child, as judgment was often granted by default. Greenberg JA noted in Fletcher v Fletcher(1948 1 SA 130 (A)):

"(T)he majority of matrimonial cases go by default, and in such cases, unless the court has some reason to doubt the plaintiff's capacity to look after the minor offspring of the marriage, and order granting him or her the custody will usually follow as a matter of course upon the main order. The Court has ordinarily in such cases no material from which to judge whether the children will be better off with the plaintiff or with the defendant, beyond the fact that the latter has not taken the trouble to claim custody."

Over the next few years the court developed certain guidelines or factors to be considered when determining what is in the best interests of the child (French v French 19714 SA 298 (W)). However, it was only in 1994 that the court in McCall (McCall v McCall 19943 SA 201) finally established a comprehensive list of factors deemed relevant in determining the best interests of a child. Palmer made reference to the court's decision as follows:

"This approach is a step in the right direction as far as article 3 of the Convention dictates. Although it will always be difficult to determine with exactitude what is in the best interests of a child in any particular case, given 
the infinite possibilities that may present themselves, the court now at least had on hand a guideline/framework in terms of which they could make an objective assessment of the case before it. The concern remained however that subjective assessments of what could be considered in the best interest of the child would potentially occur" (Palmer "The Best Interest Criterion: An Overview of its Application in Custody Decisions Relating to Divorce in the Period 1985-1995" Childrens Rights 28)."

In South Africa the commitment of the legal system to promote and develop the principle of best interests of the child cannot be doubted. SlothNielsen and Mezmur underscore this commitment in their article (" $2+2=5$ Exploring the Domestication of the CRC in South African Jurisprudence (2002-2006)" International Journal of Children's Rights 200816 1-28), and conclude that the legislator and the courts have achieved this inter alia because of the maturing of the constitutional project overall as well as the role played by the Committee on the Rights of the Child in monitoring implementation in the various participating countries. Referring to the Convention the above authors conclude that its principles have become "an essential frame of reference in the South African legal system, a foundation underpinning the building of our human rights system" (27). The entrenchment and protection of the principle in the Constitution resulted in an unprecedented application of the principle of best interests of the child in cases before the court. The paramountcy of the rights of the child is not debatable. Furthermore, according to section 39(1)(b) of the Constitution, a South African court is obligated to consider international law when interpreting the Bill of Rights. Section 233 of the Constitution expressly specifies that the court must "prefer any reasonable interpretation of legislation that is consistent with the international law over any alternative interpretation that is inconsistent with international law". As a consequence hereof, the Convention enjoys a "heightened status in the South African Legal Framework" (Sloth-Nielsen "Children's Rights in the South African Courts: An Overview since Ratification of the UN Convention on the Rights of the Child" 2002 International Journal of Children's Rights 137 139). The reason for this heightened status is twofold: firstly the Convention has been constitutionalized in section 28 of the Constitution and secondly, as mentioned above, the Constitution makes it mandatory for the court to consider international law when interpreting the Bill of Rights. The Legislature, in keeping with the provisions of the Constitution and the dictates of the Convention, promulgated the Children's Act of 2005. Section 7 of this Act provides that when a child's best interests must be determined certain factors must be taken into consideration where relevant, namely:

"(a) the nature of the personal relationship between -

(i) the child and the parents, or any specific parent; and

(ii) the child and other any care-giver or person relevant in those circumstances;

(b) the attitude of the parents, or any specific parent, towards -

(i) the child; and

(ii) the exercise of parental responsibilities and rights in respect of the child; 
(c) the capacity of the parents, or any specified parent, or of any other caregiver or person, to provide for the needs of the child, including emotional and intellectual needs;

(d) the likely effect on the child of any change in the circumstances, including the likely effect on the child of any separation from -

(i) both or either of the parents; or

(ii) any brother or sister or other child, or any other care-giver or person with whom the child has been living;

(e) the practical difficulty and expense of a child having contact with the parents, or any specific parent, and whether that difficulty or expense will substantially affect the child's right to maintain personal relations and direct contact with parents, or any specific parent, on a regular basis;

(f) the need for the child -

(i) to remain in the care of his or her parent, family and extended family; and

(ii) to maintain a connection with his or her family, extended family, culture or tradition;

(g) the child's age, maturity and stage of development;

(ii) gender;

(iii) background; and

(iv) any other relevant characteristics of a child;

(h) the child's physical and emotional security and his or her intellectual, emotional, social and cultural development;

(i) any disability that a child may have;

(j) any chronic illness from which a child may suffer;

(k) the need for a child to be brought up within a stable family environment and, where this is not possible in an environment resembling as closely as possible a caring family environment;

(I) the need to protect the child from physical or psychological harm that may be caused by -

(i) subjecting the child to maltreatment, abuse, neglect, exploitation or degradation or exposing the child to violence or harmful behaviour towards another person;

(m) any family violence involving the child or a family member of the child; and

(n) which action or decision would avoid or minimise further legal or administrative proceedings in relation to the child."

Section 9 of the same Act reiterates the fact that the standard of best interest of a child is of paramount importance and must be applied in all matters concerning the care, protection and well-being of the child. Assisting the court in reaching a decision that is considered to be in the best interest of the child, is the Family Advocate. In terms of the Mediation in Certain Divorce Matters Act (24 of 1987), the Family Advocate may approach the court to request the court's permission to undertake an enquiry, with the assistance of a Family Counsellor. On completion of a report, the Family Advocate will make a recommendation to court concerning the welfare and best interests of the children concerned. The principles of the Constitution must be adhered to and the provisions of the Children's Act of 2005 are considered in making such recommendation.

From the discussion above it is apparent that the family-law system and the structure in South Africa comply with the principles of the Convention. Of 
importance is the detailed substantive consideration of the concept of "best interests of the child".

\section{Conclusion}

In both Mauritius and South Africa there were significant attempts and the commitment to incorporate the principles reflected in the Convention. Mauritius has established the Ombudsperson for Children, and South Africa makes use of the already established office of the Family Advocate. The effective functioning of the Ombudsperson as well as its precise role in practice has not been fully developed in Mauritius, however.

There is also no legislative enactment setting out the factors to consider when the best interests of the child is to be determined. Mauritius may be well advised to consider the model of the Family Advocate in South Africa, or to define the functions of the Ombudsperson clearly.

Such a development as well as substantive legislature guidelines as to the meaning of the "best interests of the child" will go a long way to ensure substantial compliance with the (already ratified) Convention.

The interests of children are of utmost importance and there should be no further delay in this regard in Mauritius.

Glynis van der Walt Nelson Mandela Metropolitan University, Port Elizabeth 